\title{
SUTURE-BUTTON VERSUS SYNDESMOTIC SCREW IN THE TREATMENT OF DISTAL TIBIOFIBULAR SYNDESMOSIS INJURY: A SYSTEMATIC REVIEW OF LITERATURE AND META-ANALYSIS
}

\author{
Mohamed Mokhtar Abdellah", Islam Koriem Fattouh", and \\ Abdelrahman Fathi Ahmed Eisa
}

Orthopedic Surgery and Traumatology Department, Faculty of Medicine, Ain Shams University, Egypt

** Manshiet El Bakry General Hospital

Corresponding author Abdelrahman Fathi Ahmed Eisa Mobile: (+2) 01127113677

E.mail:

abdofathieisa@gmail.com

Received :26/4/2021

Accepted: 25/5/2021

Online ISSN: 2735-3540

\begin{abstract}
Background: Ankle fractures are one of the most common types of fractures, comprising $18 \%$ of all skeletal injuries annually. These fractures frequently involve the distal tibiofibular syndesmosis. The syndesmosis is vital in stabilizing the ankle mortise and transmitting load during weight bearing. In this study we reviewed the literature for comparison between suture button and syndesmotic screw fixation.
\end{abstract}

Aim of the work: A Systematic review to compare between suture button and syndesmotic screw fixation in distal tibiofibular syndesmotic injuries.

Methods: This systematic review consisted of 5 RCTs, including a systematic search of literature (PubMed/medline, National Library of Medicine, and The Cochrane Library), selection of studies, extraction of study characteristics, assessment of methodological quality and bias and extraction of data on clinical outcomes and their comparisons between different surgical groups using revman 5.2.

Results: A total of 5 RCTs were included, 347 patients were extracted from the included studies. Of the 347 patients, 170 (48.991\%) had undergone suture button fixation and 177 (51.008\%) had undergone syndesmotic screw fixation. The minimum follow-up duration was 12 months. These procedures were done using standard AO technique. suture button group had significantly higher AOFAS score with less implant failure (before 8 weeks), malreduction rates and reoperation (not including routine screw removal), with higher rate of wound infection.

Conclusion: We concluded that the suture-button device could lead to better objective range of motion measurements and earlier return to work, besides, the suture-button fixation group had lower rate of implant removal, implant failure, and malreduction. Multicenter randomized clinical trials are needed to obtain a highquality level of evidence for the comparison between suture button and syndesmotic screw.

Keywords: Syndesmosis, ankle, suture button, tightrope and screw.

\section{INTRODUCTION:}

Ankle fractures are one of the most common types of fractures, comprising $18 \%$ of all skeletal injuries annually. These fractures frequently involve the distal tibiofibular syndesmosis. The syndesmosis is vital in stabilizing the ankle mortise and transmitting load during weight bearing. ${ }^{(1-2)}$

Anatomic restoration and stabilization of the disrupted distal tibiofibular syndesmosis is necessary for optimal functional outcome. ${ }^{(3-4)}$ 
Inadequate reduction of syndesmosis can lead to late arthrosis and instability that is correlated with poor subjective and objective outcomes. ${ }^{(1-3,5)}$

Methods of treatment include syndesmotic screw and suture button fixation. Optimal surgical management is still a subject of debate in the literature. ${ }^{(3,6)}$

Understanding of the distal tibiofibular syndesmotic biomechanics is essential in formulating treatment algorithms. There is a normal physiologic motion between the tibia and fibula at the distal tibiofibular joint during plantar flexion and dorsiflexion of the foot, which appears as approximately 1-2 $\mathrm{mm}$ of widening at the mortise. (2-7-8) $^{-}$

Though screw fixation is the goldstandard in treatment of syndesmotic injury, some significant issues should be considered, such as screw loosening, breakage, discomfort, reoperation, loss of reduction due to early implant removal. ${ }^{(9-10)}$

More recently, the suture-button fixation device has aroused the attention of many orthopedists. This device has been reported with some potential advantages, such as allowing of physiological movement while retaining the required reduction, less risk of implant removal and recurrent syndesmotic diastasis, and earlier rehabilitation. ${ }^{(1-11)}$

\section{MATERIAL AND METHODS}

Criteria for considering studies for this review:

\section{Types of studies:}

We included randomized control trails (RCTs) and controlled clinical trials. We excluded case reports, case series studies, cross-sectional studies and quasi-random. Search results exported to systematic review management software and manually screened for duplication and eligibility (revman 5.2). PRISMA flowchart was produced based on the search results and the inclusion/exclusion criteria ${ }^{(12)}$.

Types of participants:

Types of interventions:

1. Suture button fixation

2. Syndesmotic screw fixation

Types of outcome measures:

1. AOFAS score

2. Orleude molander score

3. Implant failure (before 8 weeks).

4. Malreduction

5. Reoperation (not including routine screw removal)

6. Wound infection Search strategy for identification of
studies:

Locating and selecting studies:

We searched MED-LINE database, PubMed, National Library of Medicine, Cochrane Register of Controlled Trails (The Cochrane Library) using the following

\section{Data extraction:}

The following data were extracted; patient demographics, surgical technique, functional outcomes, and complications. Our primary outcome was the AOFAS score. The secondary outcomes included orleude molander score, implant failure, malreduction, wound infection and reoperation (not including routine screw removal).

\section{Statistical considerations:}

PRISMA flowchart was produced based on the search results and the inclusion/exclusion criteria, to facilitate the assessment of possible the risk of bias for each study, information was assessed using the (Cochrane collaboration tool for assessing the risk of bias) ${ }^{(13)}$.

\section{Statistical analysis}


Dichotomous variables, including the implant failure, malreduction, wound infection, and reoperation, the relative treatment effect was reported as the risk ratio (RR) and $95 \%$ confidence interval $(\mathrm{CI})$. For continuous data, including AOFAS and Orleude molander scores. The effect of treatment was quantified by calculating the mean difference with $95 \%$ CI. Heterogeneity across the pooled data was formally tested

\section{RESULTS:}

\section{Studies and assessment of study quality:}

Our search retrieved 5 RCTs in total that met our inclusion criteria after removing duplicates and excluding non-eligible studies (diagram 1).

\section{Risk of bias assessment:}

The assessment risk of bias was done according to Cochrane risk of bias tool by using the Cochrane c2 test and quantified using the 2 tests. An I 2 of $<50 \%$ was the cut off for homogeneity of the data using the Fixed effects model, justifying pooling. The random effects model was applied if the I2 was $>50 \%$ and heterogeneity was significant. Differences were considered significant if $p<0.05$. Statistical analysis of all the extracted data was performed using Review Manager software, version 5.3 ${ }^{(14)}$. conducting data of each included study to the Revman computer program ${ }^{(14)}$. The Cochrane risk of bias consisting of 6 items (randomization generation, allocation concealment, blinding of participant and personnel, blinding of outcome assessment, incomplete outcome data, selective reporting). Answering to each item by low risk, unclear risk, high risk (diagram 2 and diagram 3).

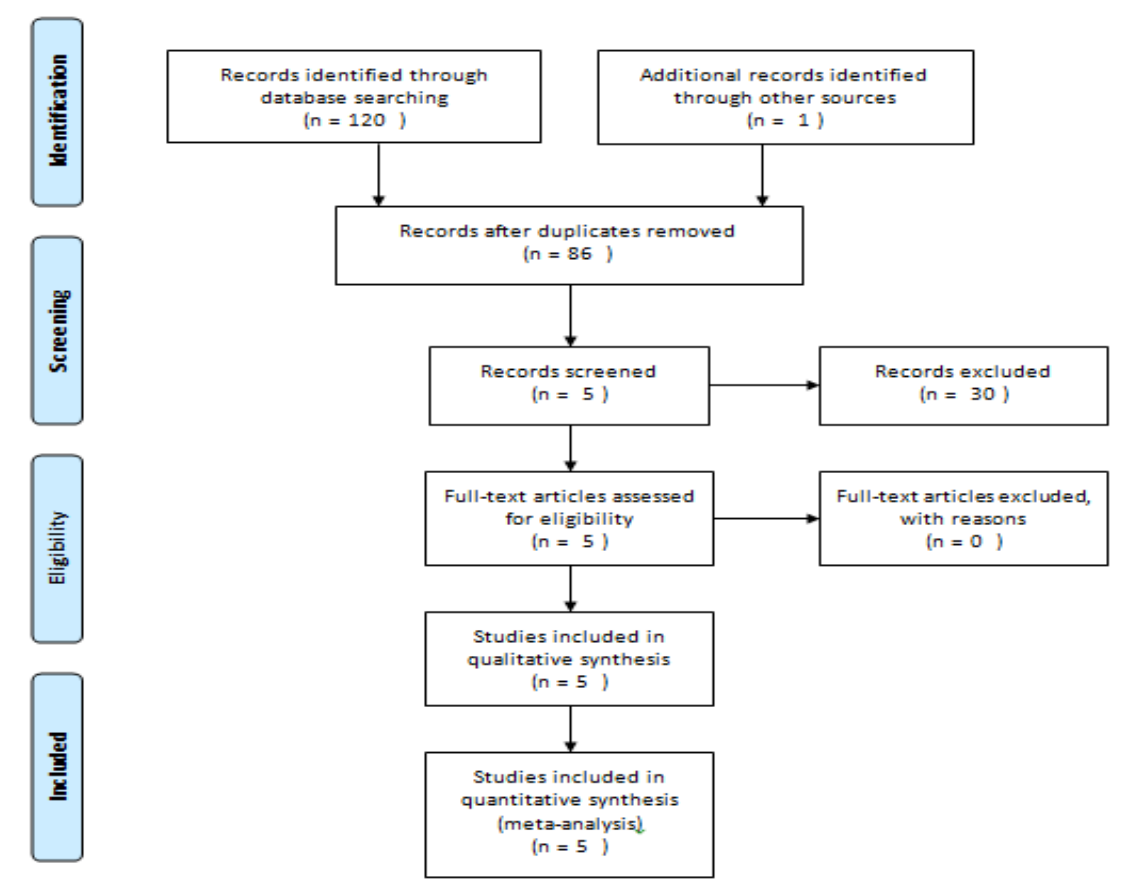

Diagram (1): PRISMA flow chart of selected studies. 
Mohamed Mokhtar Abdellah, et al.

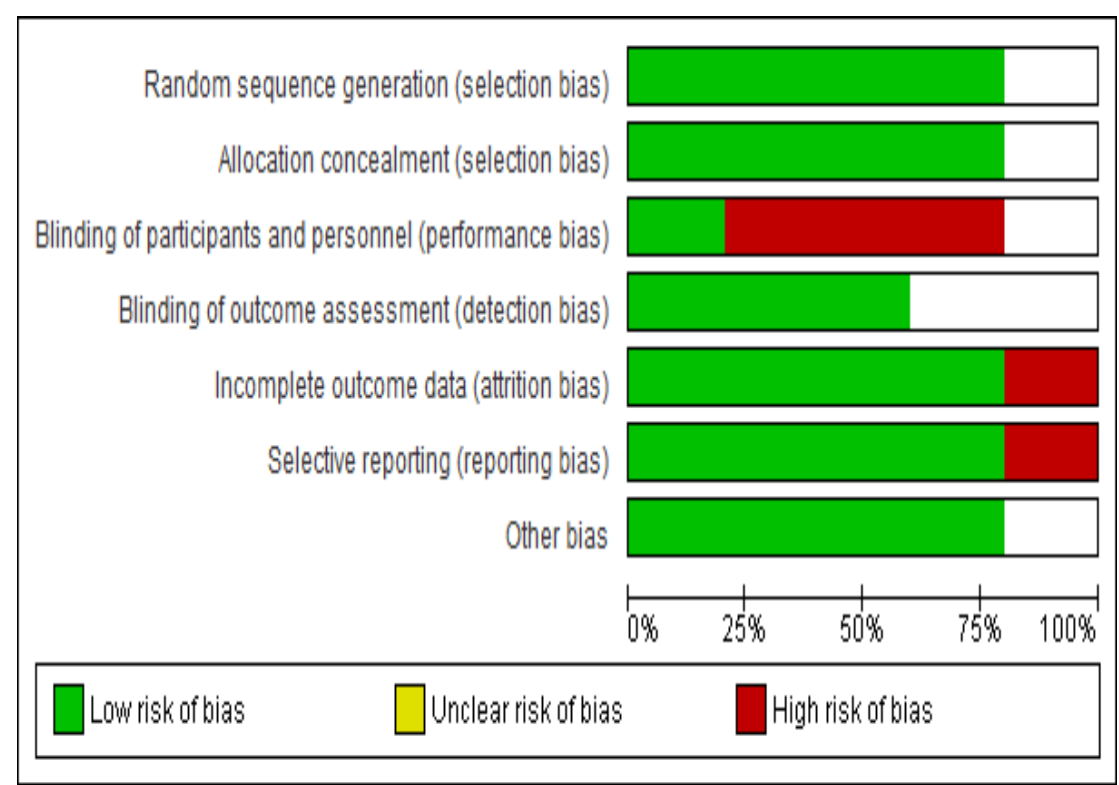

Diagram (2): Risk of bias graph presented as percentages across all included studies.

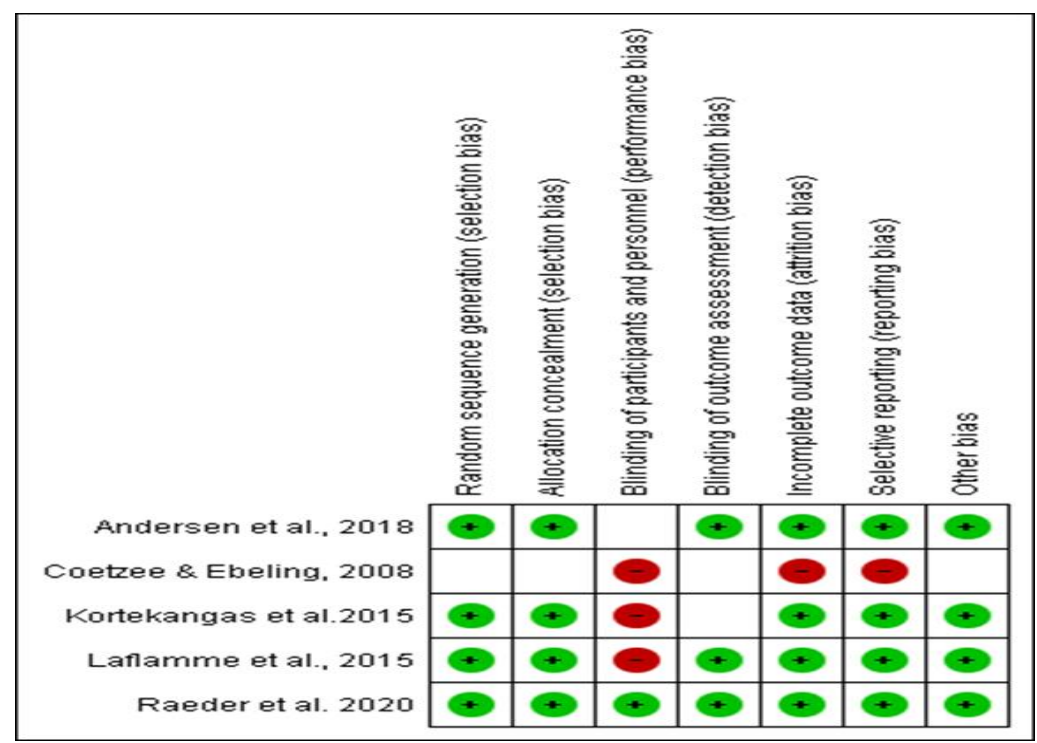

\section{Baseline patient characteristics:}

The data from a total of 347 patients were extracted from the included studies. Of the 347 patients, $170 \quad(48.991 \%)$ had undergone suture button fixation and 177 $(51.008 \%)$ had undergone syndesmotic screw fixation. The minimum follow-up duration was 12 months. These procedures were done using standard $\mathrm{AO}$ technique (table 1A,B,C). 
Suture-button versus syndesmotic screw in the treatment of distal tibiofibular syndesmosis injury:..

Table (1A): The characteristics of the included studies

\begin{tabular}{|c|c|c|c|c|c|c|}
\hline Study (year) & Study (type) & $\begin{array}{c}\text { Number } \\
\text { SBG.VS } \\
\text { SG }\end{array}$ & $\begin{array}{c}\text { Mean age } \\
\text { (years): } \\
\text { SBG VS SG }\end{array}$ & $\begin{array}{l}\text { Suture-button } \\
\text { usage }\end{array}$ & $\begin{array}{l}\text { Cortical screw } \\
\text { usage }\end{array}$ & Follow-up \\
\hline $\begin{array}{ll}\text { Ræder } & \text { BW } \\
2020^{(59)} & \end{array}$ & $\begin{array}{l}\text { prospective } \\
\text { randomized study }\end{array}$ & $55 / 58$ & $44 / 48$ & $\begin{array}{l}\text { Single } \\
\text { knotless SB }\end{array}$ & $\begin{array}{l}\text { Fully threaded } \\
\text { self-tapping, } 3.5 \\
\text { mm tricortical } \\
\text { screw }\end{array}$ & 2 years \\
\hline $\begin{array}{l}\text { Andersen } \\
2018^{(46)}\end{array}$ & $\begin{array}{l}\text { proospective } \\
\text { randomized study }\end{array}$ & $48 / 49$ & $34.7 / 24.2$ & $\begin{array}{l}\text { tightrope } \\
\text { (Arthrex) }\end{array}$ & $\begin{array}{l}\text { Fully threaded, } \\
\text { self-tapping, } \\
4.5-\mathrm{mm} \text { cortical } \\
\text { syndesmotic } \\
\text { screw }\end{array}$ & 2 years \\
\hline $\begin{array}{l}\text { Kortekangas } \\
2015^{(1)}\end{array}$ & $\begin{array}{l}\text { Prospective } \\
\text { randomized } \\
\text { controlled clinical } \\
\text { trial }\end{array}$ & $21 / 22$ & $46.0 / 43.5$ & $\begin{array}{l}1 \text { TightRope } \\
\text { implant }\end{array}$ & $\begin{array}{lr}\text { (Synthes) } & \\
\text { One } & 3.5 \mathrm{~mm} \\
\text { screw } & (3 \\
\text { cortices) } & \end{array}$ & $\begin{array}{l}\text { At least } 2 \text { years, } \\
\text { mean } 36 \text { months } \\
\text { in the syndes- } \\
\text { motic screw } \\
\text { group) }\end{array}$ \\
\hline $\begin{array}{l}\text { Laflamme } \\
2015^{(47)}\end{array}$ & $\begin{array}{l}\text { Prospective } \\
\text { randomized } \\
\text { multicenter trial }\end{array}$ & $34 / 36$ & $40.1 / 39.3$ & $\begin{array}{l}1 \text { Tight Rope } \\
\text { implant }\end{array}$ & $\begin{array}{lr}\text { One } & 3.5 \mathrm{~mm} \\
\text { screw } & (4 \\
\text { cortices }) & \\
\end{array}$ & 12 months \\
\hline $\begin{array}{l}\text { Coetzee } \\
2009^{(48)}\end{array}$ & $\begin{array}{l}\text { Prospective, } \\
\text { randomized } \\
\text { clinical trial }\end{array}$ & $12 / 12$ & $35 / 38$ & $\begin{array}{l}\text { All but one } \\
\text { had two } \\
\text { TightRopes }\end{array}$ & $\begin{array}{l}4.0 \mathrm{~mm}, 4.5 \mathrm{~mm} \\
\text { and } 6.5 \mathrm{~mm} \\
\text { screws }\end{array}$ & 2.3 year \\
\hline
\end{tabular}

SBG suture-button group, SG screw group

Table (1B): The characteristics of the included studies

\begin{tabular}{|c|c|c|c|c|c|c|c|}
\hline Study (year) & $\begin{array}{l}\text { Main } \\
\text { functional } \\
\text { evaluation }\end{array}$ & $\begin{array}{c}\text { Mean } \\
\text { scores } \\
\text { SBG VS } \\
\text { SG }\end{array}$ & $\begin{array}{c}\text { Implant } \\
\text { removal } \\
\text { SBG VS } \\
\text { SG } \\
\end{array}$ & $\begin{array}{l}\text { Implant } \\
\text { failure } \\
\text { SBG VS } \\
\text { SG }\end{array}$ & $\begin{array}{l}\text { Malreduction } \\
\text { SBG VS SG }\end{array}$ & $\begin{array}{l}\text { Complications } \\
\text { SBG VS SG }\end{array}$ & $\begin{array}{l}\text { Routine } \\
\text { screw } \\
\text { removal (yes } \\
\text { or no) } \\
\end{array}$ \\
\hline $\begin{array}{l}\text { Ræder } \\
2020\end{array}$ & AOFAS & $97 / 97$ & $4 / 12$ & $2 / 1$ & $3 / 3$ & $\begin{array}{l}10 \text { patients in the SB } \\
\text { group and } 17 \text { patients in } \\
\text { the TS group had } \geq 1 \\
\text { reoperation }\end{array}$ & No \\
\hline Andersen 2018 & AOFAS & $96 / 86$ & $11 / 8$ & $0 / 1$ & $1 / 3$ & $\begin{array}{l}15 \text { patients in each } \\
\text { group had } \geq 1 \\
\text { reoperations in addition } \\
\text { to routine screw } \\
\text { removal }\end{array}$ & Yes \\
\hline $\begin{array}{l}\text { Kortekangas } \\
2015\end{array}$ & $\begin{array}{l}\text { Olerud- } \\
\text { Molander } \\
\text { score }\end{array}$ & $82 / 84$ & $1 / 3$ & $\begin{array}{l}0 / 16 \text { (broken } \\
\text { in three } \\
\text { patients and } \\
\text { loosened in } \\
13 \text { patients) } \\
\end{array}$ & $1 / 3$ & $\begin{array}{lr}1 & \text { post-operative } \\
\text { infection/3 } & \text { local } \\
\text { irritation } & \end{array}$ & No \\
\hline $\begin{array}{l}\text { Laflamme } \\
2015\end{array}$ & $\begin{array}{l}\text { Olerud- } \\
\text { Molander } \\
\text { score }\end{array}$ & $93.3 / 87.7$ & $2 / 11$ & $0 / 13$ & $0 / 4$ & $\begin{array}{l}3 \text { (two superficial } \\
\text { infection and one partial } \\
\text { syndesmosis } \\
\text { ossification } 12 \text { (1 partial } \\
\text { syndesmosis } \\
\begin{array}{l}\text { ossification and } 11 \\
\text { discomfort) }\end{array}\end{array}$ & No \\
\hline Coetzee 2009 & AOFAS & $94 / 88$ & $1 / 1$ & $0 / 1$ & NR & 1 superficial infection/0 & No \\
\hline
\end{tabular}

AOFAS American Orthopedic Foot and Ankle Society ankle score, SG screw group, NR no report 
Table (1C): The characteristics of the included studies

\begin{tabular}{|c|c|c|c|c|}
\hline Study (year) & $\begin{array}{c}\text { Rehabitation process } \\
\text { (SBG) }\end{array}$ & $\begin{array}{c}\text { Rehabitation process } \\
\text { (SG) }\end{array}$ & $\begin{array}{c}\text { Time to full } \\
\text { weight bearing } \\
\text { (weeks) } \\
\text { SBG VS SG } \\
\end{array}$ & Key findings \\
\hline $\begin{array}{l}\text { Ræder } \quad \text { BW } \\
2020\end{array}$ & $\begin{array}{l}\text { Plaster casts and thrombosis } \\
\text { prophylaxis were not used } \\
\text { routinely. Patients were } \\
\text { advised partial weight- } \\
\text { bearing }(20-30 \mathrm{~kg}) \text { directly } \\
\text { after surgery then weight- } \\
\text { bearing as tolerated after } 6 \\
\text { weeks }\end{array}$ & $\begin{array}{l}\text { Plaster casts and } \\
\text { thrombosis prophylaxis } \\
\text { were not used routinely. } \\
\text { Patients were advised } \\
\text { partial weight-bearing (20- } \\
30 \mathrm{~kg}) \text { directly after } \\
\text { surgery then weight- } \\
\text { bearing as tolerated after } 6 \\
\text { weeks }\end{array}$ & $6 \mathrm{w}$ & $\begin{array}{l}\text { No clinically relevant differences } \\
\text { regarding outcome scores } \\
\text { between the groups }\end{array}$ \\
\hline Andersen 2018 & $\begin{array}{l}\text { Both groups were } \\
\text { encouraged to bear partial } \\
\text { weight from } 2 \text { to } 6 \text { weeks } \\
\text { after the surgery and to } \\
\text { begin full weight-bearing as } \\
\text { tolerated at } 6 \text { weeks }\end{array}$ & $\begin{array}{l}\text { Both groups were } \\
\text { encouraged to bear partial } \\
\text { weight from } 2 \text { to } 6 \text { weeks } \\
\text { after the surgery and to } \\
\text { begin full weight-bearing } \\
\text { as tolerated at } 6 \text { weeks }\end{array}$ & $6 w$ & $\begin{array}{l}\text { We found that use of an SB for } \\
\text { the treatment of syndesmotic } \\
\text { injuries in patients between } 18 \\
\text { and } 70 \text { years old resulted in } \\
\text { higher AOFAS and OMA scores } \\
\text { and better radiographic outcomes } \\
\text { than use of } 1 \text { quadricortical SS }\end{array}$ \\
\hline $\begin{array}{l}\text { Kortekangas } \\
2015\end{array}$ & $\begin{array}{l}\text { A below-the-knee cast with } \\
\text { the ankle joint at a } 90^{\circ} \text { for } 6 \\
\text { weeks with partial weight } \\
\text { bearing. At } 6 \text { weeks, the cast } \\
\text { was removed, the ankle was } \\
\text { examined, and a research } \\
\text { physiotherapist instructed } \\
\text { the patient in rehabilitation } \\
\text { exercises. No additional } \\
\text { bracing was used and weight } \\
\text { bearing was allowed as } \\
\text { tolerated }\end{array}$ & $\begin{array}{l}\text { A below-the-knee cast } \\
\text { with the ankle joint at a } \\
90^{\circ} \text { for } 6 \text { weeks with } \\
\text { partial weight bearing. At } \\
6 \text { weeks, the cast was } \\
\text { removed, the ankle was } \\
\text { examined, and a research } \\
\text { physiotherapist instructed } \\
\text { the patient in } \\
\text { rehabilitation exercises. } \\
\text { No additional bracing was } \\
\text { used and weight bearing } \\
\text { was allowed as tolerated }\end{array}$ & NR & $\begin{array}{l}\text { Syndesmotic screw and } \\
\text { TightRope had similar } \\
\text { postoperative malreduction rates. } \\
\text { After at least } 2 \text { years of follow- } \\
\text { up, malreduction rates may } \\
\text { slightly increase when using } \\
\text { trans-syndesmotic screw fixation, } \\
\text { but reduction was well maintained } \\
\text { when fixed with TightRope. } \\
\text { Neither the incidence of ankle } \\
\text { joint osteoarthritis nor functional } \\
\text { outcome significantly differed } \\
\text { between the fixation methods }\end{array}$ \\
\hline Laflamme 2015 & $\begin{array}{l}\text { No weight bearing in a cast } \\
\text { for } 6 \text { weeks and then } \\
\text { rehabilitation } \\
\text { protection }\end{array}$ & $\begin{array}{l}\text { No weight bearing in a } \\
\text { cast for } 6 \text { weeks and then } \\
\text { rehabilitation without } \\
\text { protection }\end{array}$ & NR & $\begin{array}{l}\text { Dynamic fixation seems to result } \\
\text { in better clinical and radiographic } \\
\text { outcomes. The implant offers } \\
\text { adequate syndesmotic } \\
\text { stabilization without failure or } \\
\text { loss of reduction, and the } \\
\text { reoperation rate is significantly } \\
\text { lower than with conventional } \\
\text { screw fixation. }\end{array}$ \\
\hline Coetzee 2009 & $\begin{array}{l}\text { A short leg cast splint for } \\
\text { two weeks with non-weight } \\
\text { bearing and then a } \\
\text { pneumatic Cam boot was } \\
\text { applied for partial weight } \\
\text { bearing. At six weeks, Cam } \\
\text { boot removal for weight } \\
\text { bearing it the syndesmosis } \\
\text { appears stable and any } \\
\text { associated fractures were } \\
\text { healed }\end{array}$ & $\begin{array}{l}\text { A short leg cast splint for } \\
\text { two weeks with non- } \\
\text { weight bearing and then a } \\
\text { pneumatic Cam boot was } \\
\text { applied for partial weight } \\
\text { bearing. At six weeks, } \\
\text { Cam boot removal for } \\
\text { weight bearing it the } \\
\text { syndesmosis appears } \\
\text { stable and any associated } \\
\text { fractures were healed }\end{array}$ & NR & $\begin{array}{l}\text { The TightRope®fiber wire } \\
\text { fixation group had a statistically } \\
\text { significant better range of motion } \\
\text { compared to conventional screw } \\
\text { fixation. The AOFAS ankle and } \\
\text { hindfoot score did not show a } \\
\text { significant difference between the } \\
\text { two groups at medium term } \\
\text { follow-up }\end{array}$ \\
\hline
\end{tabular}




\begin{tabular}{|c|c|c|c|c|c|c|c|c|c|c|c|}
\hline \multirow[b]{2}{*}{ Study or Subgroup } & \multicolumn{3}{|c|}{ SB group } & \multicolumn{3}{|c|}{ SS group } & \multicolumn{3}{|c|}{ Mean Difference } & \multirow{2}{*}{\multicolumn{2}{|c|}{$\begin{array}{l}\text { Mean Difference } \\
\text { IV, Random, } 95 \% \mathrm{Cl}\end{array}$}} \\
\hline & Mean & SD & Total & Mean & SD & Total & Weight & IV, Random, $95 \% \mathrm{Cl}$ & & & \\
\hline Andersen et al., 2018 & 96 & 2.75 & 48 & 87 & 4 & 49 & $30.9 \%$ & $9.00[7.64,10.36]$ & & & - \\
\hline Coetzee \& Ebeling, 2008 & 85.2 & 8.75 & 12 & 75.5 & 9.75 & 12 & $16.6 \%$ & $9.70[2.29,17.11]$ & & & \\
\hline Laflamme et al., 2015 & 93.1 & 9.3 & 33 & 89.9 & 12.7 & 32 & $21.4 \%$ & $3.20[-2.22,8.62]$ & & & \\
\hline Raeder et al. 2020 & 93 & 4 & 53 & 90 & 1.5 & 52 & $31.1 \%$ & $3.00[1.85,4.15]$ & & & + \\
\hline Total $(95 \% \mathrm{Cl})$ & & & 146 & & & 145 & $100.0 \%$ & $6.01[1.64,10.38]$ & & & \\
\hline \multicolumn{9}{|c|}{$\begin{array}{l}\text { Heterogeneity. } \text { Tau }^{2}=15.64 ; C h i^{2}=45.34, d f=3(P<0.00001) ; I^{2}=93 \% \\
\text { Test for overall effect: } Z=2.69(P=0.007)\end{array}$} & $\longmapsto^{-20}$ & $\begin{array}{l}-10 \\
\text { Favours SS }\end{array}$ & Favours SB \\
\hline
\end{tabular}

Forest plot of comparison: 1 Comparison between SB group and SS group, outcome: $1.1 \mathrm{AOFAS}$ score at 1 year.

Diagram (4): Forest plot of comparison: 1 Comparison between SB group and SS group, outcome: 1.1 AOFAS score at 1 year.

Four included studies measured button group in AOFAS score with $\mathrm{P}$ value functional outcome according to AOFAS $=0.007$ and (RR 6.01, 95\% CI, 1.64-10.38). score, The pooled results from the meta- Heterogeneity was found as the $\mathrm{I}^{2}$ is $93 \%$ analysis showed Statistical significance between the two groups towards the suture (diagram 4).

\begin{tabular}{|c|c|c|c|c|c|c|c|c|c|c|c|c|}
\hline \multirow[b]{2}{*}{ Study or Subgroup } & \multicolumn{3}{|c|}{ SB group } & \multicolumn{3}{|c|}{ SS group } & \multirow[b]{2}{*}{ Weight } & \multirow{2}{*}{$\begin{array}{l}\text { Mean Difference } \\
\text { IV, Random, } 95 \% \mathrm{Cl}\end{array}$} & & \multirow{2}{*}{\multicolumn{2}{|c|}{$\begin{array}{c}\text { Mean Difference } \\
\text { IV, Random, } 95 \% \mathrm{Cl}\end{array}$}} & \\
\hline & Mean & SD & Total & Mean & SD & Total & & & & & & \\
\hline Andersen et al., 2018 & 95 & 2.75 & 48 & 85 & 6.75 & 49 & $33.8 \%$ & $10.00[7.96,12.04]$ & & & 블 & \\
\hline Laflamme et al., 2015 & 93.3 & 10.2 & 33 & 97.7 & 12.2 & 32 & $32.5 \%$ & $-4.40[-9.88,1.08]$ & & & & \\
\hline Raeder et al. 2020 & 90 & 6.2 & 47 & 100 & 4.1 & 45 & $33.8 \%$ & $-10.00[-12.14,-7.86]$ & & 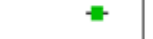 & & \\
\hline Total $(95 \% \mathrm{Cl})$ & & & 128 & & & 126 & $100.0 \%$ & $-1.43[-16.19,13.33]$ & & & & \\
\hline $\begin{array}{l}\text { Heterogeneity: Tau }{ }^{2}=1 \\
\text { Test for overall effect: } z\end{array}$ & $\begin{array}{l}6.85 ; \mathrm{Ch} \\
0.19(\mathrm{P}\end{array}$ & $\begin{array}{l}\mathrm{i}^{2}=1 \\
=0.85\end{array}$ & $\begin{array}{l}78.35,0 \\
\text { 5) }\end{array}$ & $d f=2(P$ & $<0.00$ & $0001) ; l^{2}$ & $\left.\right|^{2}=99 \%$ & & $! 50$ & $\begin{array}{c}-25 \\
\text { Favours SS }\end{array}$ & avours SB & 50 \\
\hline
\end{tabular}

Forest plot of comparison: 1 Comparison between SB group and SS group, outcome: $1.2 \mathrm{OM}$ score at 1 year.

Diagram (5): Forest plot of comparison: 1 Comparison between SB group and SS group, outcome: 1.2 OM score at 1 year.

Three included studies measured functional outcome according to orleud molander score, The pooled results from the meta-analysis showed almost no Statistical

significance between the two groups with $\mathrm{P}$ value $=0.85$ and $(\mathrm{RR}-1.43,95 \% \mathrm{CI},-16.9$ 13.33). Heterogeneity was found as the $\mathrm{I}^{2}$ is 99\% (diagram 5).

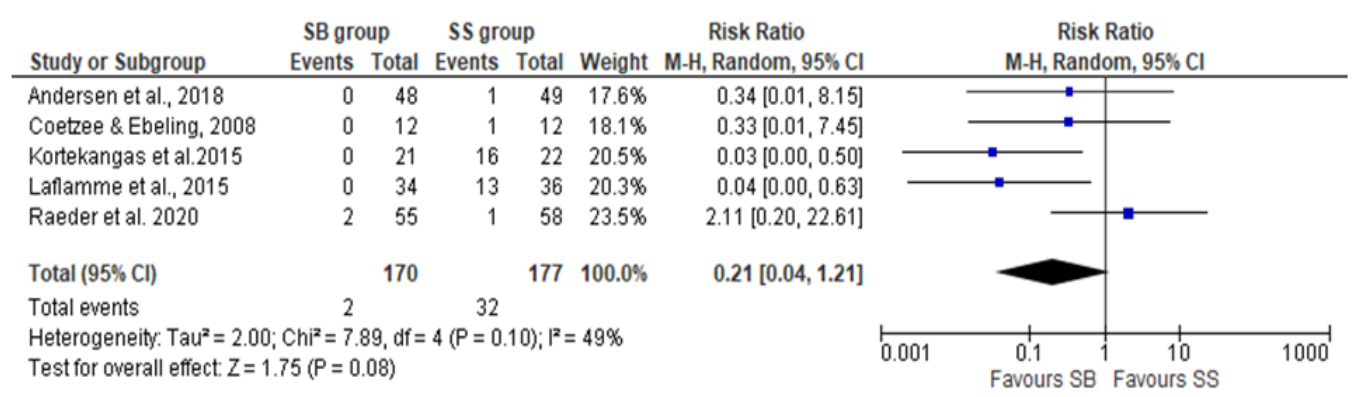

Forest plot of comparison: 1 Comparison between SB group and SS group, outcome: 1.3 Implant failure. 
Diagram (6): Forest plot of comparison: 1 Comparison between SB group and SS group, outcome: 1.3 Implant failure.

All included studies reported implant failure, 2 out of 170 patients in the suture button group and 32 out of 177 in the syndesmotic screw group, The pooled results from the meta-analysis showed statistical significance between the two groups towards the suture button group with $\mathrm{P}$ value $=0.08$ and (RR 0.21, 95\% CI, 0.04-1.21). Heterogeneity was found as the $\mathrm{I}^{2}$ is $49 \%$ (diagram 6).

\begin{tabular}{|c|c|c|c|c|c|c|c|c|c|c|}
\hline \multirow[b]{2}{*}{ Study or Subgroup } & \multicolumn{2}{|c|}{ SB group } & \multicolumn{2}{|c|}{ SS group } & \multicolumn{2}{|c|}{ Risk Ratio } & \multirow{2}{*}{\multicolumn{4}{|c|}{$\begin{array}{c}\text { Risk Ratio } \\
\text { M-H, Fixed, } 95 \% \mathrm{Cl}\end{array}$}} \\
\hline & Events & Total & Events & Total & Weight & M-H, Fixed, $95 \% \mathrm{Cl}$ & & & & \\
\hline Andersen et al., 2018 & 1 & 48 & 3 & 49 & $22.5 \%$ & $0.34[0.04,3.16]$ & & & & \\
\hline Kortekangas et al.2015 & 1 & 21 & 3 & 22 & $22.2 \%$ & $0.35[0.04,3.10]$ & & & & \\
\hline Laflamme et al., 2015 & 0 & 34 & 4 & 36 & $33.2 \%$ & $0.12[0.01,2.10]$ & & & & \\
\hline Raeder et al. 2020 & 3 & 55 & 3 & 58 & $22.1 \%$ & $1.05[0.22,5.00]$ & & & & \\
\hline Total $(95 \% \mathrm{Cl})$ & & 158 & & 165 & $100.0 \%$ & $0.43[0.16,1.12]$ & & & & \\
\hline Total events & 5 & & 13 & & & & & & & \\
\hline $\begin{array}{l}\text { Heterogeneity: } \text { Chi }^{2}=2.1 \\
\text { Test for overall effect: } Z=\end{array}$ & $\begin{array}{l}\mathrm{df}=3(\mathrm{P} \\
.72(\mathrm{P}=\end{array}$ & $\begin{array}{l}=0.54 \\
0.08)\end{array}$ & $4) ; 1^{2}=0 \%$ & & & & 0.01 & $\begin{array}{ll}0.1 & 1 \\
\text { Favours SB }\end{array}$ & $\begin{array}{r}10 \\
\text { Favours SS }\end{array}$ & 100 \\
\hline
\end{tabular}

Forest plot of comparison: 1 Comparison between SB group and SS group, outcome: 1.4 Malreduction.

Diagram (7): Forest plot of comparison: 1 Comparison between SB group and SS group, outcome: 1.4 Malreduction.

Four studies included reported malreduction, 5 out of 158 patients in the suture button group and 13 out of 165 in the syndesmotic screw group, The pooled results from the meta-analysis showed statistical

significance between the two groups towards the suture button group with $\mathrm{P}$ value $=0.08$ and (RR 0.43, 95\% CI, 0.16-1.12).with no Heterogeneity as $\mathrm{I}^{2}$ was found $0 \%$ (diagram 7).

\begin{tabular}{|c|c|c|c|c|c|c|c|c|c|c|}
\hline \multirow[b]{2}{*}{ Study or Subgroup } & \multicolumn{2}{|c|}{ SB group } & \multicolumn{2}{|c|}{ SS group } & \multicolumn{2}{|r|}{ Risk Ratio } & \multirow{2}{*}{\multicolumn{4}{|c|}{$\begin{array}{c}\text { Risk Ratio } \\
\text { M-H, Fixed, } 95 \% \mathrm{Cl}\end{array}$}} \\
\hline & Events & Total & Events & Total & Weight & M-H, Fixed, $95 \% \mathrm{Cl}$ & & & & \\
\hline Andersen et al., 2018 & 15 & 48 & 15 & 49 & $31.9 \%$ & $1.02[0.56,1.85]$ & & & & \\
\hline Coetzee \& Ebeling, 2008 & 1 & 12 & 0 & 12 & $1.1 \%$ & $3.00[0.13,67.06]$ & & & & \\
\hline Kortekangas et al.2015 & 1 & 21 & 3 & 22 & $6.3 \%$ & $0.35[0.04,3.10]$ & & & & \\
\hline Laflamme et al., 2015 & 3 & 34 & 12 & 36 & $25.1 \%$ & $0.26[0.08,0.86]$ & & & & \\
\hline Raeder et al. 2020 & 10 & 55 & 17 & 58 & $35.6 \%$ & $0.62[0.31,1.23]$ & & & & \\
\hline Total $(95 \% \mathrm{Cl})$ & & 170 & & 177 & $100.0 \%$ & $0.67[0.45,1.00]$ & & & & \\
\hline Total events & 30 & & 47 & & & & & & & \\
\hline $\begin{array}{l}\text { Heterogeneity. } \mathrm{Ch}^{2}=5.62 \\
\text { Test for overall effect: } \mathrm{Z}=\end{array}$ & $\begin{array}{l}d f=4(P= \\
98(P=0 .\end{array}$ & $\begin{array}{l}=0.23) ; \\
.05)\end{array}$ & $I^{2}=29 \%$ & & & & 0.02 & 0.1 Favours SB & Favours SS & 50 \\
\hline
\end{tabular}

Forest plot of comparison: 1 Comparison between SB group and SS group, outcome: 1.5 Reoperation not including routine screw removal.

Diagram (8): Forest plot of comparison: 1 Comparison between SB group and SS group, outcome: 1.5 Reoperation not including routine screw removal.

All included studies reported Reoperation (not including routine screw removal), 30 out of 170 patients in the suture button group and 47 out of 177 in the syndesmotic screw group, The pooled results from the meta-analysis showed statistical significance between the two groups towards the suture button group with $\mathrm{P}$ value $=0.05$ and (RR 0.67, 95\% CI, 0.45-1.00). Heterogeneity was found as the $\mathrm{I}^{2}$ is $29 \%$ (diagram 8). 


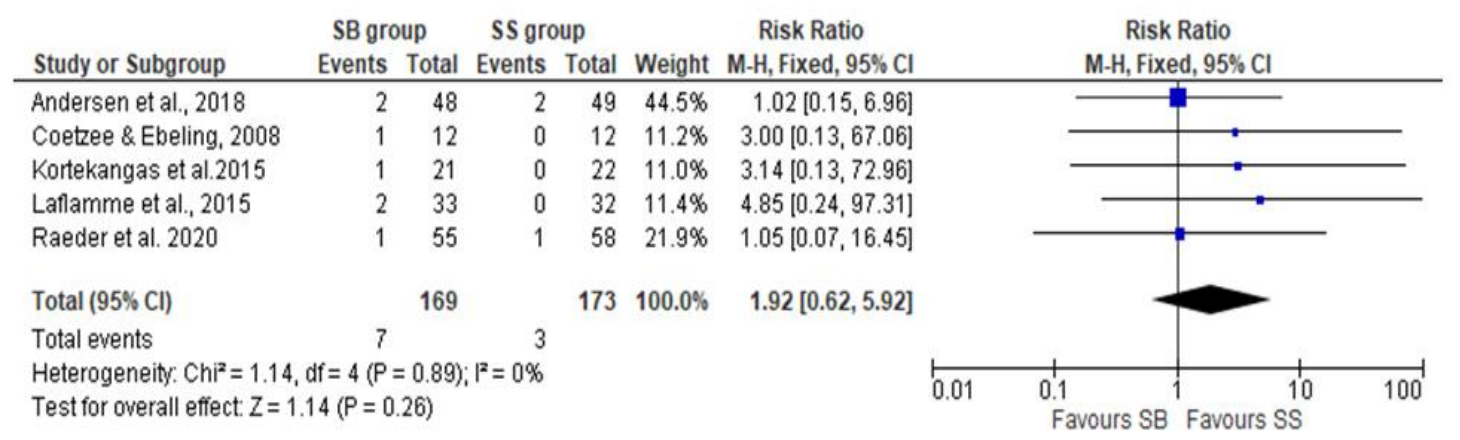

Forest plot of comparison: 1 Comparison between SB group and SS group, outcome: 1.6 Wound infection

Diagram (9): Forest plot of comparison: 1 Comparison between SB group and SS group, outcome: 1.6 Wound infection.

All included studies reported wound infection, 7 out of 170 patients in the suture button group and 3 out of 177 in the syndesmotic screw group, The pooled results from the meta-analysis showed statistical significance between the two groups towards the syndesmotic screw group with $\mathrm{P}$ value $=$ 0.26 and (RR 1.92, 95\% CI, 0.62-5.92) with no Heterogeneity as the $\mathrm{I}^{2}$ was found $0 \%$ (diagram 9).

\section{DISCUSSION:}

Regarding AOFAS in the first year, the suture button group had better results than the syndesmotic screw group including 4 RCTs. Raeder et al, Andersen et al., Coetzee et al., and Laflamme et al. ${ }^{(15-16-17-19)}$

The difference between the two groups according to AOFAS score was increasing with time .as example in Andersen et, al the median AOFAS score differed significantly between the groups from 6 months ( 2 points) onward. At 2 years the between-group difference was 10 points. ${ }^{(15)}$

While in Raeder et al., there were almost no difference between the 2 groups, hence the need for more objective scale to eliminate the patients subjective differences in AOFAS scale. ${ }^{(19)}$
The AOFAS is not validated it is criticized for low precision, and for producing skewed data due to ceiling effects. ${ }^{(20)}$ The AOFAS was chosen because of its widespread use.

Regarding Olerude molander score in the first year, the suture button group and the syndesmotic group were almost the same in 3 RCTs. Raeder et al, Andersen et al and Laflamme et al., ${ }^{(15-16-19)}$

Regarding Malreduction there were 5 cases in the suture button group and 13 cases in the syndesmotic screw group including 4 RCTs. Raeder et al, Andersen et al, Laflamme et al and Kortekangas et al. ${ }^{(15-16-}$ 18-19)

As accurate anatomic reduction of the syndesmosis is the most important clinical outcome, the need for post-operative CT increases to evaluate the reduction of the syndesmosis. Bilateral imaging is recommended due to remarkable individual variation in measurements of syndesmosis width.

In Raeder BW 3 patients in the SB group and 3 patients in the SS group required early reoperation $(<3$ weeks) after CT postoperatively revealed unacceptable reduction of the fracture or of the syndesmosis (3 syndesmosis 


\section{Mohamed Mokhtar Abdellah, et al.}

malreductions, 1 fibula malreduction, 2 medial malleolus malreduction).

Two RCTs standardized CT in their post operative evaluation Raeder et al., and Kortekangas et al. ${ }^{(18-19)}$ while two studies used fluoroscopy Andersen et al., and Laflamme et al.. Coetzee et al did not specify. ${ }^{(15-16)}$

Regarding implant failure there were 2 cases in the suture button group and 32 cases in the syndesmotic screw group including all 5 RCTs.

Statistically significant lower implant failure rate with the SB group because of the dynamic nature of the implant. Literature reports SS implant failure at $6.78 \%$ mostly a broken screw. ${ }^{(21)}$

Regarding reoperation (not including routine screw removal) there were 30 cases in the suture button group and 47 cases in the syndesmotic screw group including all 5 RCTs.

Reoperation may be due to local irritation, infection, implant failure, and loss of reduction either to syndesmosis or the fracture itself.

Only Andersen et al. did routine screw removal which has been claimed to restore the normal tibiofibular relationship and avoid limitations in range of motion which is controversial according to literature that demonstrated that early screw removal before ligamentous healing is associated with risk of recurrent syndesmotic diastasis. (15-22)

Schepers et al. found no clear benefits of screw removal. Routine screw removal is also associated with wound infection rates of $5 \%$ to $9 \%{ }^{(22)}$.

However reoperation should be less in suture button group. In Andersen et al., 6\% of the patients in the SB group required SB removal within 2 years, because of the knot on the lateral side, ${ }^{(15)}$ Raeder BW used knotless suture button to avoid irritation but he had a $9 \%$ removal rate. ${ }^{(19)}$

Changing to a knotless SB did not affect the removal rate. This could be due to other factors, such as irritation from the fibular plate.

Regarding Wound Infection there were 7 cases in the suture button group and 3cases in the syndesmotic screw group including all 5 RCTs.

Fantry considered that braided sutures within the SB implant provided a conducive environment for the development of infection across the syndesmotic fixation tract, suggesting the need for prompt infectious workup in the presence of suture button migration or osteolysis. ${ }^{(23)}$

Another study analyse RCTs comparing SB and SS fixation but we have more cases total of 347 while Ongoo et al has 288 cases. (24)

Ongoo et, al concluded that SB and SS constructs yielded similar clinical outcomes ${ }^{(24)}$. While our study concluded that SB fixation group had better functional outcomes (measured on the AOFAS and olerude-molander score) and post-operative complication rate compared with the SS fixation group, the suture-button device could lead to better objective range of motion measurements and earlier return to work. Besides, the suture-button fixation group had lower rate of implant removal, implant failure, and malreduction.

Limitations of our study: was that difference in the type and number of screws used also number of cortices engaged we need to unify all aspects for a better comparison.

Our recommendation in future studies to include mandatory post operative $\mathrm{CT}$ to exclude malreduction. A more objective functional scale for better assessment of functional outcome. The need to standerdize the follow up protocol to early weight 
bearing to benefit from the dynamic nature of the suture button. the need for a longer follow up and larger number of patients is mandatory to diagram out which is the best method for fixation of syndesmotic injuries.

\section{Conclusion}

Based on our research, the suture-button fixation group had better functional outcomes (measured on the AOFAS score) and post-operative complication rate compared with the syndesmotic screw fixation group, so the suture-button device could lead to better objective range of motion measurements and earlier return to work. Besides, the suture-button fixation group had lower rate of implant removal, implant failure, and malreduction.

The key aspects for future research we recommend cost-effectiveness study of the TightRope system versus a syndesmotic screw.

\section{REFERENCES:}

1. Kortekangas T, Savola O, Flinkkila T, Lepojarvi S, Nortunen S, Ohtonen P, et al. (2015): A prospective randomized study comparing TightRope and syndesmotic screw fixation for accuracy and maintenance of syndesmotic reduction assessed with bilateral computed tomography. Injury; 46(6):1119-26.

2. Bonnel, F., Toullec, E., Mabit, C., Tourné, Y., \& Sofcot (2010): Chronic ankle instability: biomechanics and pathomechanics of ligaments injury and associated lesions. Orthopaedics \& traumatology, surgery \& research: OTSR, 96(4), 424-432.

3. Cottom JM, Hyer CF, Philbin TM, Berlet GC. (2009): Transosseous fixation of the Distal tibiofibular syndesmosis: comparison of an interosseous suture and endobutton to traditional screw fixation in 50 cases. The Journal of Foot and Ankle Surgery; 48(6): 620-30.
4. Pang EQ, Bedigrew K, Palanca A, Behn AW, Hunt KJ \& Chou L (2019): Ankle joint contact loads and displacement in syndesmosis injuries repaired with Tightropes compared to screw fixation in a static model. Injury, 50(11), 1901-1907.

5. Chissell HR, Jones J (1995): The influence of a diastasis screw on the outcome of Weber type-C ankle fractures. J Bone Joint Surg Br; 77: 435-438.

6. Kim JH, Gwak HC, Lee CR, Choo HJ, Kim JG, Kim DY. (2016): A comparison of Screw fixation and suture-button fixation in a syndesmosis injury in an ankle fracture. The Journal of Foot and Ankle Surgery; 55(5):985-90.

7. Teramoto A, Kura H, Uchiyama E, Suzuki D \& Yamashita T (2008): Threedimensional analysis of ankle instability after tibiofibular syndesmosis injuries: a biomechanical experimental study. The American journal of sports medicine, 36(2), 348-352.

8. Wagener ML, Beumer A \& Swierstra BA (2011): Chronic instability of the anterior tibiofibular syndesmosis of the ankle. Arthroscopic findings and results of anatomical reconstruction. BMC musculoskel et al disorders, $12, ; 212$.

9. Kocadal O, Yucel M, Pepe M, Aksahin E, Aktekin CN. (2016): Evaluation of reduction accuracy of suture-button and screw fixation techniques for Syndesmotic injuries. Foot Ankle Int; 37(12): 1317-25.

10. Magan A, Golano P, Maffulli N, Khanduja $\mathrm{V}$ (2014): Evaluation and management of injuries of the tibiofibular syndesmosis. $\mathrm{Br}$ Med Bull; 111(1):101-115.

11. Xu G, Chen W, Zhang Q, Wang J, Su Y, Zhang Y. (2013): Flexible fixation of syndesmotic diastasis using the assembled bolt-tightrope system. Scand J Trauma Resusc Emerg Med; 21(1):71.

12. Welch V, Petticrew M, Petkovic J, Moher $\mathrm{D}$, et al. (2016): Extending the PRISMA statement to equity-focused systematic reviews (PRISMA-E 2012): explanation and elaboration. J Dev Effect; 70: 68-89. 
13. Savovic J, Weeks L, Sterne J, Turner L, et al. (2014): Evaluation of the Cochrane Collaboration's tool for assessing the risk of bias in randomized trials: focus groups, online survey, proposed recommendations and their implementation. Syst Rev, 3.

14. The Cochrane Collaboration. RevMan 5 | Cochrane Community. Cochrane Community; 2014.

15. Andersen MR, Frihagen F, Hellund JC, Madsen JE, Figved W. (2018): Randomized trial comparing suture button with single syndesmotic screw for syndesmosis injury. J Bone Joint Surg Am; 100(1): 2-12.

16. Laflamme M, Belzile EL, Bedard L, van den Bekerom MP, Glazebrook M, Pelet S. (2015): A prospective randomized multicenter trial comparing clinical outcomes of patients treated surgically with a static or dynamic implant for acute ankle syndesmosis rupture. J Orthop Trauma; 29(5): 216-23.

17. Coetzee JC, Ebeling PB. (2009): Treatment of syndesmoses disruptions: a prospective randomized study comparing conventional screw fixation vs. TightRope1fiber wire fixation - medium term results. SA Othop J; 8(1):

18. Kortekangas $\mathrm{T}$, Savola $\mathrm{O}$, Flinkkila $\mathrm{T}$, Lepojarvi S, Nortunen S, Ohtonen P, et al. (2015): A prospective randomized study comparing TightRope and syndesmotic screw fixation for accuracy and maintenance of syndesmotic reduction assessed with bilateral computed tomography. Injury; 46(6):1119-26.
19. Ræder BW, Stake IK, Madsen JE, Frihagen F, Jacobsen SB, Andersen MR, \& Figved W (2020): Randomized trial comparing suture button with single $3.5 \mathrm{~mm}$ syndesmotic screw for ankle syndesmosis injury: similar results at 2 years. Acta orthopaedica, 91(6), 770-775.

20. Veltman ES, Hofstad CJ, Witteveen AGH (2017): Are current foot- and ankle outcome measures appropriate for the evaluation of treatment for osteoarthritis of the ankle: evaluation of ceiling effects in foot- and ankle outcome measures. J Foot Ankle Surg; 23(3): 168-72.

21. van den Bekerom MP, Kloen P, Luitse JS, Raaymakers EL (2013): Complications of distal tibiofibular syndesmotic screw stabilization: analysis of 236 patients. J Foot Ankle Surg; 52(4):456-9.

22. Schepers T, Van Lieshout EM, de Vries MR, Van der Elst M (2011): Complications of syndesmotic screw removal. Foot Ankle Int.; 32(11):1040-4.

23. Fantry AJ, O'Donnell SW, Born CT, Hayda RA (2017): Deep infections after syndesmotic fixation with a suture button device. Orthopedics; 40(3): e541-5.

24. Onggo JR, Nambiar M, Phan K, Hickey B, Ambikaipalan A, Hau R \& Bedi H (2020): Suture button versus syndesmosis screw constructs for acute ankle diastasis injuries: A meta-analysis and systematic review of randomised controlled trials. Foot and ankle surgery: official journal of the European Society of Foot and Ankle Surgeons, 26(1), 54-60. 
دراسة منهجية وتحليل بعدى للمقارنه بين استخدام المسمار والزر المعلق على خيط فى تثبيت

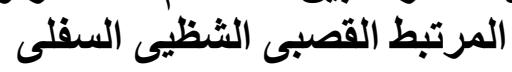

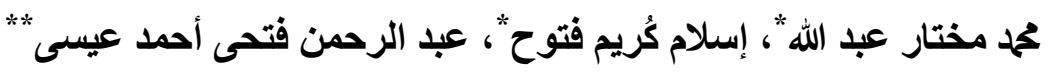

قسم جر احة العظام و الكسور ، كلية الطب، جامعة عين شمس، مصر

$$
\text { مستشفى منشية البكرى العام }
$$

المقدمة: كسور الكاحل هى واحدة من أشهر الكسور حيث تعادل ^|\\% من الكسور فى السنة. وهذه الكسور عادة ما تشمل إصابة المرتبط القصبى الثظبيى السفلى. المرتبط القصبى الثظيى السفلى حيوى فى ثبات مفصل الكاحل ونقل الوزن أثناء التحميل على القدم. فى هذه الدراسه قمنا بمراجعة المقارنات بين الزر المعلق على خيط والمسمار فى تثبيت المرتبط القصبى الثظيى

الهُف من الاراسة: هو دراسة منهجية للمقارنه بين الزر المعلق على خبط والمسمار فى علاج المرتبط القصبى

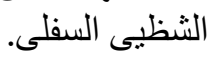

PubMed, Medline, الطرق المنهجية: هذه الدراسه المرجعيه تتكون من خمسة أبحاث تشمل البحث فى National library of medicine and the cochrane library اختيار الدراسة، واستخر اج المواصفات، وتعيين المعايير واستخر اج البيانات من النتائج العمليه و المقارنات ما بين

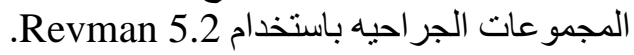

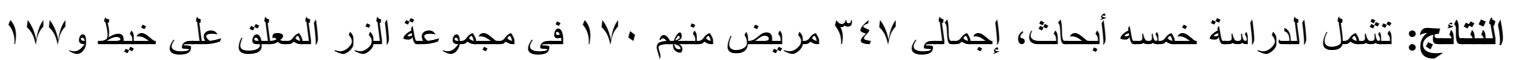

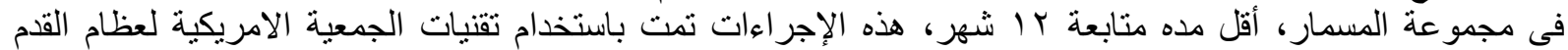

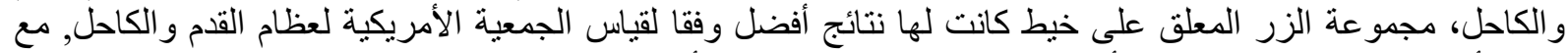

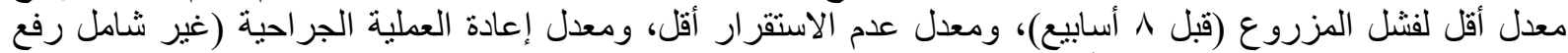
المسمار الروتينى)، مع معدل عدوى أعلى.

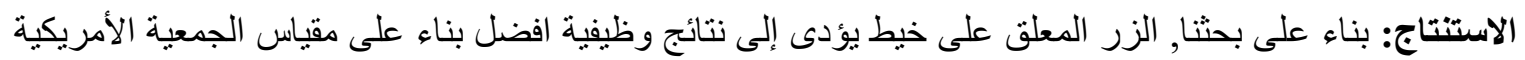
لعظام القدم و الكاحل, ومعدل المضاعفات على ما بعد العملية مقارنة بالمسمار المستعرض.

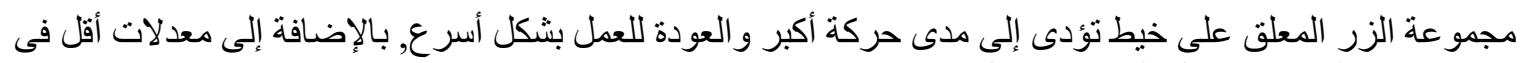

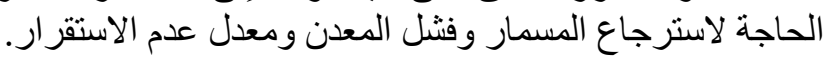

